\title{
Хірургічне лікування паціента з критичною ішемією нижніх кінцівок на фоні цукрового діабету: клінічний випадок
}

\author{
У роботі наведено клінічний випадок хірургічного лікування пацієнта з критичною ішемією нижніх кінцівок на фоні цукро- \\ вого діабету. Критична ішемія нижніх кінцівок залишається головним показанням до реконструкції артеріального русла, тому \\ що відновлення магістрального кровотоку попередить ампутацію та покращить якість життя пацієнта.
}

Ключові слова: облітеруючий атеросклероз нижніх кінцівок; критична ішемія нижніх кінцівок; цукровий діабет.

Проблема вибору індивідуалізованих клінікопатогенетично обгрунтованих підходів до методів ефективного хірургічного лікування хворих із термінальними проявами стенотично-облітеруючого процесу стегно-підколінно-гомілкового сегмента атеросклеротичного генезу залишається актуальною, динамічною [1].

У 30 \% хворих після 8 років перебігу захворювання розвивається критична ішемія, яка не тільки погіршує якість життя пацієнта, а часто є причиною ампутації. У хворих, які хворіють на цукровий діабет з наявністю інфікованих ран, реваскуляризацію виконують в ділянках із трофічними змінами. Лікування пацієнтів 3 критичною ішемією вимагає комплексних заходів [2].

Критична ішемія нижніх кінцівок залишається головним показанням до реконструкції артеріального русла, тому що відновлення магістрального кровотоку попередить ампутацію та покращить якість життя пацієнта [3-5].

Враховуючи тяжкість захворювання, особливості перебігу критичної ішемії на фоні цукрового діабету, наводимо клінічний випадок.

Клінічний випадок. Згідно з випискою із карти стаціонарного хворого № 00001 Тернопільської університетської лікарні хворий В., 1966 року народження, госпіталізований у відділення судинної хірургії зі скаргами на постійний ниючий біль в правій стопі та м'язах гомілки, що посилюються в нічний період, порушення сну внаслідок наявності больового синдрому, перестезії обох гомілок та ступней, мерзлякуватість обох нижніх кінцівок, наявність рани на п’ятковій поверхні правої ступні.

Зі слів пацієнта відомо, що вважає себе хворим близько 6 місяців, коли вперше відчув біль у правій гомілці, що виник при ходінні. Протягом останнього тижня симптоми наросли, сон порушений через больовий синдром.

Протягом останніх 15 років хворіє на цукровий діабет, цукор крові корегує таблетованими препара- тами, приймає глюкофаж. Вірусні гепатити, туберкульоз, венеричні захворювання заперечує. Алергологічний та спадковий анамнези не обтяжені.

Об'єктивно: загальний стан відносно задовільний. Шкіра і видимі слизові бліді, чисті. Температура тіла $36,7^{\circ} \mathrm{C}$, пульс 72 на хвилину, ритмічний. АТ 130/70 мм рт. ст. Аускультативно діяльність серця ритмічна, тони ослаблені. Дихання через ніс вільне. Частота дихання - 18/хв. Грудна клітка нормостенічна, обидві половини беруть участь в акті дихання. Перкуторно над легенями ясний звук. Аускультативно в легенях ослаблене дихання на всьому протязі з обох боків. Живіт м'який, при глибокій пальпації не болючий. Перистальтика вислуховується. Симптоми подразнення очеревини негативні. Сечовипускання та випорожнення не порушені. Шкірні покриви нижніх кінцівок у горизонтальному положенні бліді, після нетривалого ортостазу - права стопа із багряним відтінком, пастозна. Права нижня кінцівка гіпотрофована. Стопи нижніх кінцівок на дотик прохолодні. Чутливість знижена. Активні та пасивні рухи збережені. В ділянці п'ятки по задній поверхні наявний сухий некроз м'яких тканин 2х2 см 3 навколишньою гіперемією. Пульсація артерій правої нижньої кінцівки збережена на рівні стегнової артерії дистальніше не визначається. Пульсація артерій лівої нижньої кінцівки збережена на рівні підколінної артерії, дистальніше не визначається.

Лабораторні обстеження. Біохімічний аналіз крові 16.04.2019 р. : глюкоза - 13,21 ммоль/л, сечовина - 8,9 ммоль/л, креатинін - 66 мкмоль/л, АСТ - 27,8 Од/л, АЛТ - 51,1 Од/л, білірубін - 2,4 мкмоль/л. Біохімічний аналіз крові 20.04.2019 р. : глюкоза 9,6 ммоль/л, сечовина 6,1 ммоль/л, креатинін - 45 мкмоль/л, АСТ - 21,3 Од/л, АЛТ 26,4 Од/л, білірубін - 4,6 мкмоль/л. RWD3 - 8,7 \%. HB-W3 - 8,092 mmol/l. A1-W3 - 0,581 mmol/l. С-пептид 1,65 ng/ml. Коагулограма 16.04.2019. Фібриноген - 4,32 г/л, тромбіновий час - 12,0 с, 
протромбіновий час - 10,80 с, протромбіновий індекс - 109,57 \%. Коагулограма - 20.04.2019. Фібриноген - 3,5 г/л, тромбіновий час - 10,6 с, протромбіновий час $-10,60$ с, протромбіновий індекс - 95 \%. Група крові та резус фактор A(II) резус додатній. Загальний аналіз сечі: кількість 40,0, колір с/ж, прозорість - прозора, питома вага - 1010, реакція (рН) сл. кисла, білок - 0,15 г/л, глюкоза - не виявлено, еритроцити - не виявлено, лейкоцити 1-5 в п/3, епітелій плоский. ЕКГ: ритм синусовий правильний. Гіпоксія міокарда. Гіпертрофія лівого шлуночка.

Враховуючи недостатність представлених вище даних для встановлення клінічного діагнозу, хворому провели ультразвукове обстеження артерій нижніх кінцівок. Діагностовано стенози загальної стегнової артерії в місці біфуркації 75 \% атеросклеротична бляшка, поверхнева стегнова артерія - оклюзія атероматозними масами, підколінна артерія - кровотік колатеральний низькоамплітудний стеноз $80 \%$, задня великогомілкова артерія - стеноз 60 \% кровотік низькоапмплітудний колатеральний, передня великогомілкова артерія - кровотік низькоамплітудний колатеральний. Кісточково-плечовий індекс 0,38.

Після проведення комп’ютерної аорто-ангіографії діагностовано оклюзію дистального відділу правої поверхневої стегнової артерії та проксимального відділу підколінної артерії (рис. 1) та гемодинамічно значимий стеноз атеросклеротич-
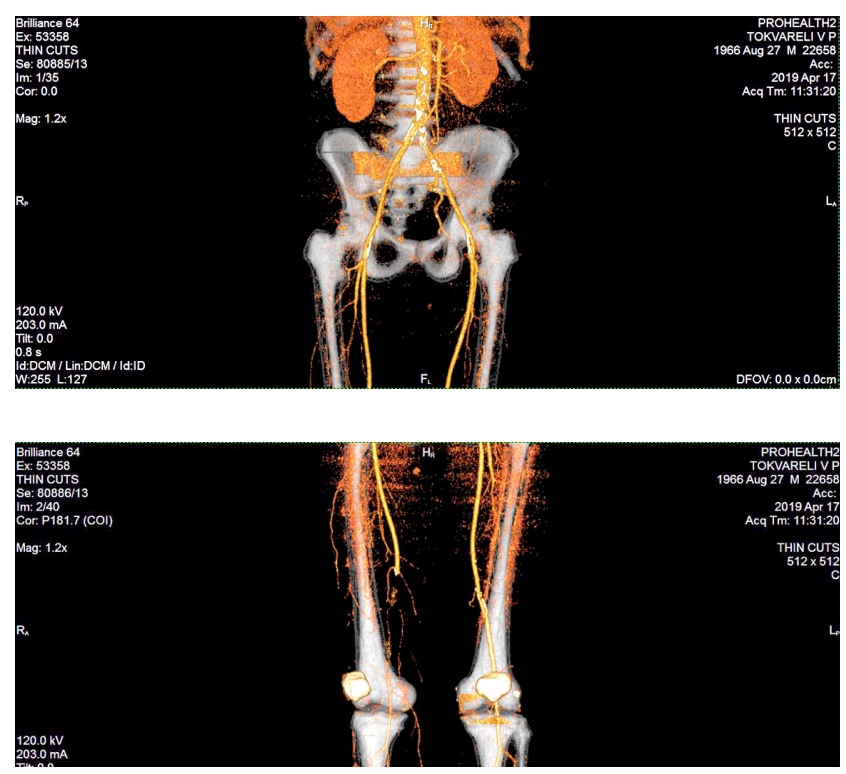

Рис. 1. КТ аорто-ангіографія нижніх кінцівок із внутрішньовенним контрастним підсиленням “Ультравіст-370” хворого В., 53 р. Оклюзія дистального відділу правої поверхневої стегнової артерії та проксимального відділу підколінної артерії. ною бляшкою загальної стегнової артерії в місці біфуркації (рис. 2), оклюзія поверхневої стегнової артерія справа, стінка атеросклеротично змінена. Перфузія лівої поверхневої стегнової артерії збережена (рис. 3). При аналізі ангіографії в ділянці колінного суглоба перфузія підколінної артерії справа відсутня (рис. 4).

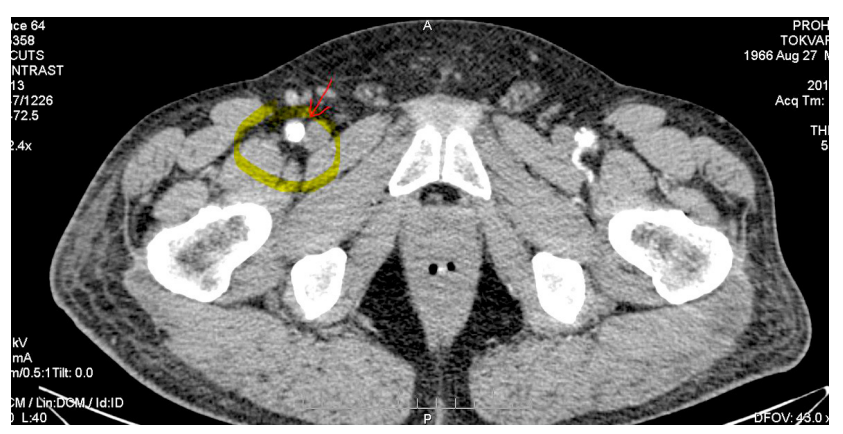

Рис. 2. КТ аорто-ангіографія нижніх кінцівок 3 внутрішньовенним контрастним підсиленням “Ультравіст-370” хворого В., 53 р. Гемодинамічно значимий стеноз атеросклеротичною бляшкою загальної стегнової артерії в місці біфуркації.

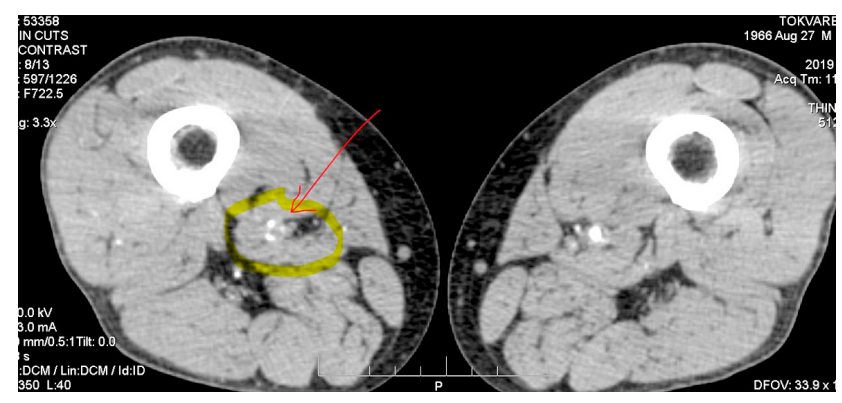

Рис. 3. КТ аорто-ангіографія нижніх кінцівок із внутрішньовенним контрастним підсиленням "Ультравіст-370” хворого В., 53 р. Оклюзія поверхневої стегнової артерії справа, стінка атеросклеротично змінена.

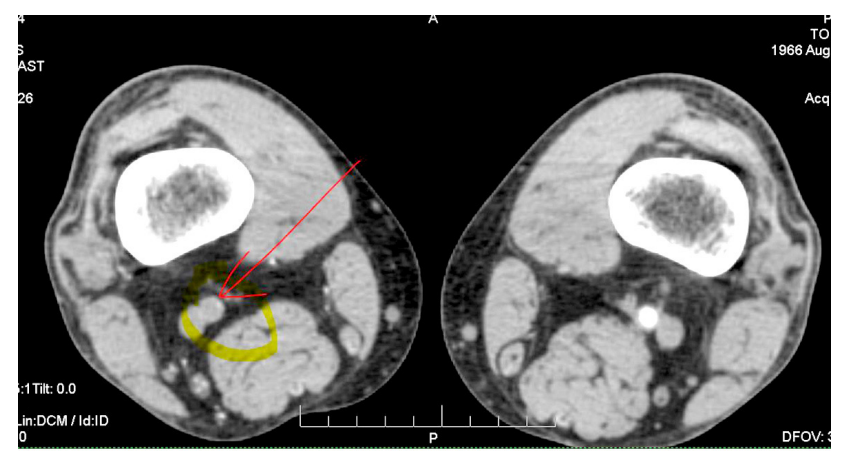

Рис. 4. КТ аорто-ангіографія нижніх кінцівок із внутрішньовенним контрастним підсиленням “Ультравіст-370” хворого В., 53 р. Оклюзія правої підколінної артерії, перфузія зліва збережена. 
Аналізуючи клініко-лабораторні та інструментальні методи обстеження у хворого встановлено клінічний діагноз: облітеруючий атеросклероз аорти та артерій нижніх кінцівок, XKIHK IV ст. справа, XАН II ст. зліва. IXC. Кардіосклероз у поєднанні з метаболічною кардіоміопатією. Артеріальна гіпертензія II ст. Високий кардіоваскулярний ризик. CH IIA ст. ФК II (NYHA). Цукровий діабет 2 тип. Середньої тяжкості, стадія субкомпенсації.

Враховуючи наявність у хворого критичної ішемії нижніх кінцівок та прогресування незворотних ішемічних змін правої нижньої кінцівки 3 подальшою можливою ампутацією кінцівки, хворому 19.04.2019 р. проведено оперативне лікування: ендартеректомія із загальної стегнової артерії справа. Стегно-підколінне автовенозне шунтування справа (рис. 5).

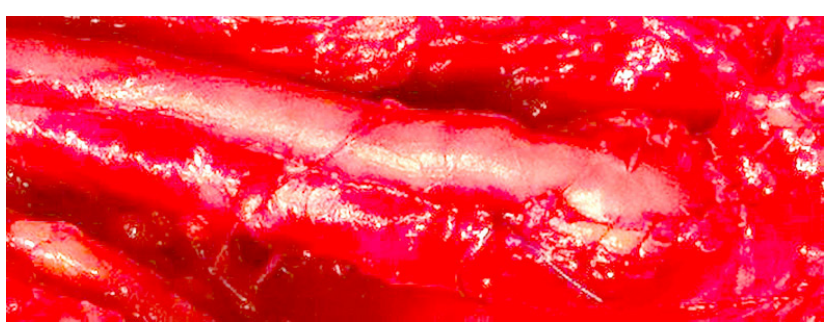

Рис. 5. Інтраопераційне фото пацієнта В., 53 р. Проксимальний автовенозний анастомоз на поверхневу стегнову артерію.

Після проведеного оперативного втручання больовий синдром в пацієнта відсутній, на порушення сну не скаржиться. Пальпаторно пульсація артерії збережена на а. dorsalis pedis.

Після проведеного ультразвукового обстеження артерій правої нижньої кінцівки від 25.04.2019 р.: загальна стегнова артерія - кровотік магістральний, d - 9,3 мм, a. dorsalis pedis - кровотік магістральний.

Кісточково-плечовий індекс збільшився з 0,38 до 0,7 .

25.04.2019 р. виконано некректомію із п'яткової поверхні правої стопи з подальшою автодермопластикою (рис. 6).

Після контрольного огляду 24.10.2019 року сегмент реконструкції функціонує, больовий синдром у правій нижній кінцівці відсутній. Трофічна рана п’яткової ділянки загоїлася вторинним натягом (рис. 7). Ознаки критичної ішемії кінцівки відсутні.

Описаний клінічний випадок показує клінічну ефективність у комплексному підході до лікування пацієнта з критичною ішемією нижніх кінцівок на фоні цукрового діабету.
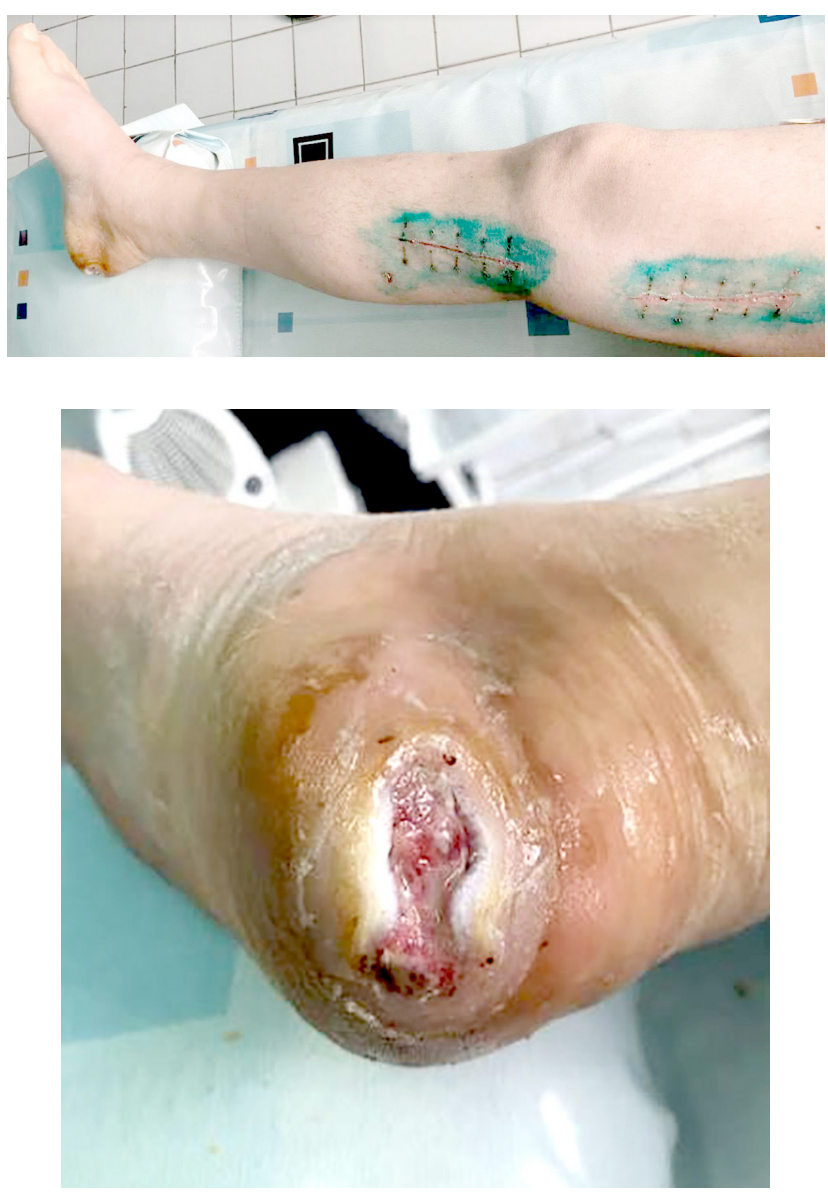

Рис. 6. Пацієнт В., права нижня кінцівка після реконструкції артеріального русла та некректомії з автодермопластикою п’яткової ділянки стопи.

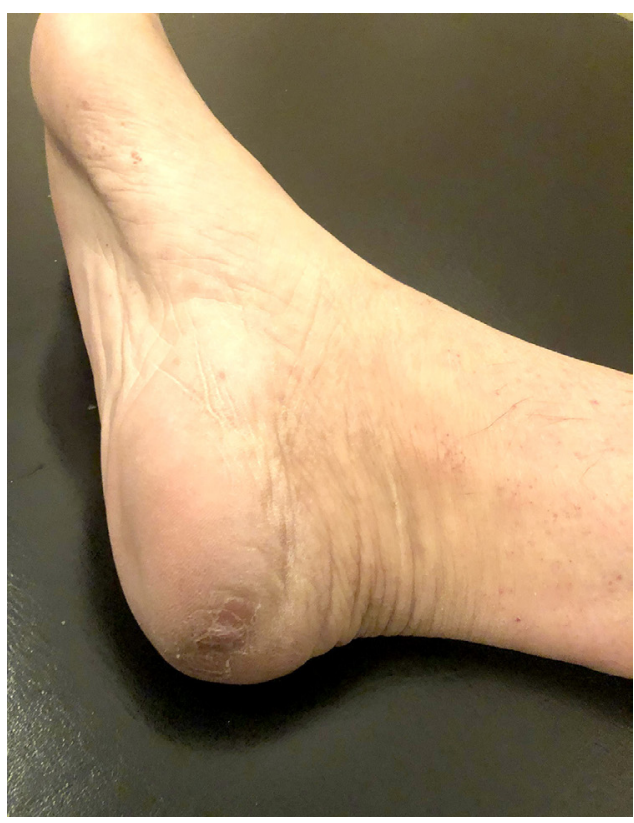

Рис. 7. Пацієнт В. Загоєння трофічної рани п’яткової ділянки правої стопи. 


\section{СПИСОК ЛІТЕРАТУРИ}

1. Vascular access in critical limb ischemia / W. Y. Kang, U. Campia, H. Ota [et al.] // Cardiovasc. Revasc. Med. - 2016. - Vol. 17 (30). - P. 190-198.

2. Ващук В. В. Досвід лікування гнійнонекротичних ускладнень синдрому діабетичної стопи : матер. конгр. XXIII з'їзд хірургів України / В. В. Ващук, Т. П. Кирик, М. І. Кушнірчук. - К., 2015.

3. Клименко В. М. Реваскуляризація нижніх кінцівок при критичній ішемії : матер. конгр : XXIII з'їзд хірургів України

\section{REFERENCES}

1. Kang, W.Y., Campia, U., Ota, H., Didier, R.J., \& Negi, S.I. (2016). Vascular access in critical limb ischemia. Cardiovasc. Revasc. Med., 17 (30), 190-198.

2. Vashchuk, V.V., Kyryk, T.P., \& Kushnirchuk, M.I. (2015). Dosvid likuvannia hniinonekrotychnykh uskladnen syndromu diabetychnoi stopy [Experience in the treatment of purulent necrotic complications of diabetic foot syndrome]. Proceedings of the Congress: XXIII zizd khirurhiv Ukrainy - XXIII Congress of Surgeons of Ukraine. Kyiv [in Ukrainian].

3. Klymenko, V.M. (2015). Revaskuliaryzatsiia nyzhnikh kintsivok pry krytychnii ishemii [Revascularization of the lower extremities in critical ischemia]. Proceedings of the Congress:
/ В. М. Клименко, І. А. - К., 2015

4. Кательницкий И. И. Влияние вида и объема восстановления кровотока на отдаленные результаты оперативного лечения пациентов с облитерирующим атеросклерозом при критической ишемии нижних конечностей / И. И. Кательницкий, Иг. И. Кательницкий // Новости Хирургии. - 2014. - № 22 (1). - С. 68-74. 5. Hennion D. R. Diagnosis and treatment of peripheral arterial disease / D. R. Hennion, K. A. Siano // American Family Physician. - 2013. - Vol. 88. - P. 306-310.
XXIII zizd khirurhiv Ukrainy - XXIII zizd khirurhiv Ukrainy. Kyiv. [in Ukrainian].

4. Katelnitskiy, I.I., \& Katelnitskiy, Ig.I. (2014). Vliyaniye vida i obyema vosstanovleniya krovotoka na otdalennyye rezultaty operativnogo lecheniya patsiyentov s obliteriruyushchim aterosklerozom pri kriticheskoy ishemii nizhnikh konechnostey [Influence of the type and volume of blood flow restoration on the long-term results of surgical treatment of patients with obliterating atherosclerosis in critical lower limb ischemia]. Novosti khirurgii - News of Surgery, 22 (1), 68-74 [in Russian].

5. Hennion, D.R., \& Siano, K.A. (2013). Diagnosis and treatment of peripheral arterial disease. American Family Physician, 88, 306-310.

\title{
SURGICAL TREATMENT OF A PATIENT WITH CRITICAL LOWER EXTREMITY ISCHEMIA ON THE BACKGROUND OF DIABETES: A GLINICAL CASE
}

\footnotetext{
The publication presents a clinical case of surgical treatment of a patient with critical lower extremity ischemia on the background of diabetes. Critical ischemia of the lower extremities remains a major indication for reconstruction of the arteries, because restoration of the main blood supply will prevent amputation and improve the quality of life of the patient.
}

Key words: obliterating atherosclerosis of the lower extremities; critical ischemia of the lower extremities; diabetes mellitus.

\author{
А. Д. БЕДЕНЮК, П. Я. БОДНАР, Т. В. БОДНАР, Ю. М. ФУТУЙМА, Л. П. БОДНАР
}

Тернопольский государственный медицинский университет имени И. Я. Горбачевского МОз Украины

\section{ХИРУРГИЧЕСКОЕ ЛЕЧЕНИЕ ПАЦИЕНТА С КРИТИЧЕСКОЙ ИШЕМИЕЙ НИЖНИХ КОНЕЧНОСТЕЙ НА ФОНЕ САХАРНОГО ДИАБЕТА: КЛИНИЧЕСКИЙ С.УУЧАЙ}

В публикации приведен клинический случай хирургического лечения пациента с критической ишемией нижних конечностей на фоне сахарного диабета. Критическая ишемия нижних конечностей остается главным показанием к реконструкции артерий, потому что восстановление магистрального кровотока предупредит ампутацию и улучшит качество жизни пациента.

Ключевые слова: облитерирующий атеросклероз нижних конечностей; критическая ишемия нижних конечностей; сахарный диабет. 